UDC 658.14.3

DOI: https://doi.org/10.32840/2522-4263/2021-1-20

Cherkashyna Maiia

Associate Professor, Candidate of Economical Science, Head of Department of Management and Military Economy National Academy of National Guard of Ukraine

Черкашина М.B. кандидат еконолічних наук, доцент, завідувач кафедри ленеджленту та військового господарства Національної акаделї̈ Національної гвардї̈ України

\title{
FINANCIAL MECHANISMS OF OPTIMIZATION OF LOGISTIC FLOWS OF THE ORGANIZATION
}

\section{ФІНАНСОВІ МЕХАНІЗМИ ОПТИМІЗАЦІї ЛОГІСТИЧНИХ ПОТОКІВ ОРГАНІЗАЦЇ̈}

\begin{abstract}
ANNOTATION
This article presents an analysis of financial mechanisms for optimizing the logistics flows of the organization. Emphasis is placed on the fact that adaptive models based on ostentatious smoothing of time series should be used to optimize the logistics flows of the organization as the main tool for short-term forecasting. In the context of this study, the main purpose of the introduction of logistical methods of managing the movement of goods is to obtain the greatest economic effect in the production of goods or services. The paper points out that the process of management and decision-making in the logistics system should be based on a system of appropriate financial indicators that characterize the effectiveness of this system. When forming such a system of indicators in the article it is recommended to calculate the following requirements: relevance, unambiguous integration, accuracy, focus on obtaining information, taking into account the main objectives of logistics. ABC analysis is used as a method to optimize the supply chain in this study. At the same time, special attention in the article is paid to such an aspect as the limited possibilities of standard distribution in $A B C$ analysis, as a result of which the specifics of a specific set may not be reflected. To this end, the paper proposes to build a curve of $A B C$ analysis. The study indicates that the sections of the curve where there is a sharp change in the radius of curvature will indicate the boundaries of groups $A, B$ and $C$ To measure the effectiveness of supply chain management, the use of a balanced scorecard BSC is proposed. The use of BSC in the context of this article is justified by the fact that this method involves measuring both financial and operational indicators used at all organizational levels of management. The paper finds that the main object of analysis of traffic management in supply chains is its functional cycle. The study of parameters based on functional cycles in this article allows you to determine the dynamics, relationships and solutions, together creating an operating system for managing the movement of goods in supply chains.
\end{abstract}

Key words: financial mechanisms, optimization, logistics flows, $A B C$ analysis, optimization, supply chains.

\section{АНОТАЦІЯ}

У даній статті подано аналіз фрінансових механізмів оптимізації логістичних потоків організації. Акцентується увага на тому, що саме адаптивні моделі, основані на показному згладжуванні часових рядів, слід застосовувати для оптимізації логістичних потоків організації у вигляді головного інструменту короткострокового прогнозування. В контексті даного дослідження головною метою впровадження логістичних методів управління рухом товарів $є$ одержання найбільшого економічного ефекту при виробництві продукції або наданні послуг. В роботі вказується, що процес управління та прийняття рішень у логістичній системі повинен ґрунтуватися на системі відповідних фрінансових показників, які характеризують ефек- тивність фрункціонування цієї системи. При формуванні такої системи показників в статті рекомендується вираховування таких вимог: актуальність, однозначність інтеграції, точність, орієнтованість на одержання інфоормації з урахуванням основних цілей логістики. У якості метода, за допомогою якого в даному дослідження проводити оптимізацію ланцюга постачань, виступає ABC-аналіз. При цьому окрему увагу в статті наділено такому аспекту, як обмеженість можливостей стандартного розподілу в ABC-аналізі, в результаті чого може не відображатися специфріка конкретної множини. 3 цією метою в роботі пропонується будувати криву ABC- аналізу. У дослідженні вказується, що ділянки кривої, на яких відбувається різка зміна радіусу кривизни, вкажуть на межі груп А, B і С. Для вимірювання ефективності управління ланцюгами поставок запропоновано використання методу збалансованої системи показників BSC. Використання BSC в контексті даної статті обґрунтовано тією обставиною, що цей метод передбачає вимірювання як фрінансових, так і операційних показників, які використовуються на всіх організаційних рівнях управління. В роботі виявлено, що основним об'єктом аналізу управління рухом товарів в ланцюгах поставок $є$ її функціональний цикл. Дослідження параметрів на підставі функціональних циклів в даній статті дозволяє визначити динаміку, взаємозв'язки і рішення, в сукупності створюючи операційну систему управління рухом товарів в ланцюгах поставок.

Ключові слова: фрінансові механізми, оптимізація, логістичні потоки, ABC-аналіз, оптимізація, ланцюги поставок.

\section{АННОТАЦИЯ}

В данной статье представлен анализ финансовых механизмов оптимизации логистических потоков организации. Акцентируется внимание на том, что именно адаптивные модели, основанные на представительном сглаживании временных рядов, следует применять для оптимизации логистических потоков организации в виде главного инструмента краткосрочного прогнозирования. В контексте данного исследования главной целью внедрения логистических методов управления товародвижением является получение наибольшего экономического эффеекта при производстве продукции или оказании услуг. В работе указывается, что процесс управления и принятия решений в логистической системе должен основываться на системе соответствующих финансовых показателей, характеризующих эфффективность функционирования этой системы. При формировании такой системы показателей в статье рекомендуется вычисления следующих требований: актуальность, однозначность интеграции, точность, ориентированность на получение информации с учетом основных целей логистики. В качестве метода, с помощью которого в данном исследования проводить оптимизацию цепочки поставок, выступает АBC-анализ. При 
этом особое внимание в статье наделены такому аспекту, как ограниченность возможностей стандартного распределения в ABC-анализе, в результате чего может не отображаться специфика конкретной множества. С этой целью в работе предлагается строить кривую АВС анализа. В исследовании указывается, что участки кривой, на которых происходит резкое изменение радиуса кривизны, укажут на грани групп $A$ В и С. Для измерения эффективности управления цепочками поставок предложено использование метода сбалансированной системы показателей BSC. Использование BSC в контексте данной статьи обоснованно тем обстоятельством что этот метод предусматривает измерение как финансовых, так и операционных показателей, используемых на всех организационных уровнях управления. В работе выявлено, что основным объектом анализа управления товародвижением в цепях поставок является ее функциональное цикл. Исследование параметров на основании функциональных циклов в данной статье позволяет определить динамику, взаимосвязи и решения, в совокупности создавая операционную систему управления товародвижением в цепях поставок.

Ключевые слова: финансовые механизмы, оптимизация логистические потоки, ABC-анализ, оптимизация, цепи поставок.

Formulation of the problem. Currently, the requirements for logistics have increased significantly. Most companies are beginning to understand the importance of logistics, its direct impact on business efficiency. The introduction of logistics principles at the enterprise guarantees a reduction in production costs and improved quality of supply, as a decisive factor in competitive advantage in the Ukrainian market. The costs of logistics of domestic companies at this stage of market development differ significantly from similar costs of companies in more developed countries. As a result, the use of financial mechanisms to optimize the logistics flows of the organization becomes important. Financial mechanisms of logistics allow to optimize the functioning of commodity, information and financial flows, significantly reduce the time between the purchase of raw materials and semi-finished products and delivery of the finished product to the consumer, contributes to a significant reduction in inventories.

Analysis of recent research and publications. Scientific articles [1-3] are devoted to issues of decision support regarding the management of logistics of the organization. Specific features of improving the quality management of high-tech enterprises on the basis of financial logistics are considered in [3-6]. Research [7; 8] systematizes web-based resources for managing the financial mechanisms of logistics processes and training in the workplace for logistics operations.

At the same time, today in the specialized literature there is no methodological approach to the analysis of financial mechanisms for optimizing the logistics flows of the organization.

Formulation of the purpose of the article (task statement). The purpose of the article is to analyze the financial mechanisms for optimizing the logistics flows of the organization.

Presenting main material. Logistics has a high potential for economic efficiency, its implementa- tion allows to realize the synergistic effect of the interaction of subsystems in open systems. That is, through the introduction of logistics companies to ensure the effect of mutual strengthening of the links of one system with another at the level of material flow or the joint effect of the interaction of elements in the system.

The purpose of implementing logistical methods of managing the movement of goods is to obtain the greatest economic effect in the production of goods or services.

The process of management and decision-making in the logistics system should be based on a system of appropriate financial indicators that characterize the effectiveness of this system. When forming such a system of indicators should calculate the following requirements: relevance, unambiguous integration, accuracy, focus on obtaining information, taking into account the main objectives of logistics

The ABC analysis is the method by which the supply chain should be optimized.

The idea of the ABC method is to select from the whole set of similar objects the most significant in terms of a particular purpose. As a rule, there are few such objects (according to the $\mathrm{Pa}$ retto rule - about $20 \%$ of the whole range), and it is on them that it is necessary to focus the main attention and strength.

When performing ABC-analysis to optimize the logistics flows of the organization should perform the following calculations:

1. The amount of the contribution for each item is calculated (number of orders, sales volume, profit, etc.).

2. The shares of individual items of the range in the total result are calculated.

3. Assortment items are arranged in the order of killing their fate in the overall result.

4. The share is calculated as a cumulative total. Thus to each previous value of a share of a position in the general result the share of the following position is added. The last cell should get value of $100 \%$.

5. The distribution of the analyzed range into groups A, B and C:

- Group A includes $20 \%$ of the items in the sorted list, starting with the most significant value. Usually these $20 \%$ correspond to $80 \%$ of the share of the cumulative total;

- group B includes the following $30 \%$ of positions. Usually group B ends $95 \%$ of the share with a cumulative result;

to group $\mathrm{C}$ include those $50 \%$ of the remaining positions or the last $5 \%$ of the share in ascending order from 95 to $100 \%$.

It should be borne in mind that the standard distribution may not reflect the specifics of a particular set. To this end, it is proposed to construct an ABC analysis curve. Areas of the curve where there is a sharp change in the radius of curvature will indicate the boundaries of groups $\mathrm{A}, \mathrm{B}$ and $\mathrm{C}$. 
It should be borne in mind that the standard distribution may not reflect the specifics of a particular set. The boundaries of the groups are not standardized and generally accepted. Almost all of the leading scientists-logists suggest using their boundaries of groups A, B and C, however, the difference between their boundaries and the above does not fundamentally change the picture of the ratio of groups.

When calculating statistical data with the subsequent distribution of spare parts by groups, calculate the accumulated specific values of their annual need in monetary terms and the percentage of the corresponding number of stocks. According to the Paretto rule, $20 \%$ of all stocks account for $80 \%$ of all costs.

Management of material flows, which constitute the essence of logistics processes, occurs in an operational mode, ie is carried out at short intervals. This scale of activity requires forecasting methods based on the analysis of time series of a particular variable (for example, which reflects the change in demand for the month). Another name for such methods is trend models (development trends).

Especially valuable are adaptive models, in which there is a so-called ostentatious smoothing of time series.

It is adaptive models based on ostentatious smoothing of time series that should be used to optimize the logistics flows of the organization as the main tool for short-term forecasting.

In the time series of demand, you can define the following elements:

- development trend (trend), which shows the general direction of development (this trend reflects the more important, continuous changes in sales);

- periodic oscillations that are repeated at equal intervals, called cycles;

- random fluctuations due to the so-called stochastic nature of socio-economic processes

The basic one-parameter Brown model, adequate to stationary time series for which the average value changes over time, is described by the dependences:

$$
\begin{gathered}
\mathrm{y}_{\mathrm{t}}=\mathrm{ay}_{\mathrm{t}}+(1-\mathrm{a}) \mathrm{y}_{\mathrm{t}-1} \\
\mathrm{y}_{\mathrm{t}+\mathrm{T}}=\mathrm{y}_{\mathrm{t}}
\end{gathered}
$$

where yt, yt-1-average values, which are calculated for the period $t$ and $t-1$;

yt - the last implementation of the predicted variable;

a is the parameter of show smoothing, the values of which lie in the interval $(0,1)$;

$\mathrm{yt}+\mathrm{T}-$ forecast the value of the variable for the period $\mathrm{t}+\mathrm{T}$.

Thus, the forecast yt $+\mathrm{T}$ demand for this product for the period $t+T$ (where $t$ is the period, for example, Sunday or month, and $t+T$ is the forecast; the value of $\mathrm{T}=\mathbf{1}$ forecast is made for the near period), is taken equal only that the cal- culated average value of yt, obtained as a result of adding the share of demand registered recently, with the share of the previous average value. Actual demand and the previous average value take part in the new average value and, as a consequence, in the new forecast, is determined by the parameter a (parameter of show smoothing).

Thus, the one-parameter Brown model is very easy to use. In order to build a forecast, it is enough to have a registered (in a card or in a computer database) estimated average value for the previous period and the latest data on the implementation of demand. It should also be noted that - despite its simplicity - the model, which is based on ostentatious smoothing of data, takes into account all the information accumulated in the past. This favorably distinguishes it from the arithmetic mean model, which is also considered an adaptive model.

The Balanced Scorecard (BSC) method is recommended to measure the effectiveness of supply chain management. The BSC method involves measuring both financial and operational indicators used at all organizational levels of management.

It is revealed that the main object of the analysis of the movement of goods in supply chains is its functional cycle. The study of its parameters on the basis of functional cycles allows to determine the dynamics, relationships and solutions, together creating an operating system for managing the movement of goods in supply chains.

Regardless of the number and variety of functional cycles that meet the management needs of the company, planning their structure and operational management must be carried out on an individual basis. The main direction is to develop the structure of the order execution cycle and control its passage. The functional cycle is the main object of planning and operational management of the movement of goods. It plays a key role in meeting management needs and creates a structural basis for managing the movement of goods.

Regular receipt of flows of goods and objects of the sphere of distribution requires certain ancillary actions, which include: the choice of source of resources; placing and sending orders; transportation; receiving delivery.

Conclusions and suggestions. Thus, the considered financial mechanisms of optimization of logistic flows of the organization allow the effective decision of a problem of management of a functional cycle. As a result, the coordination of actions to comply with the expected or regulatory deadlines for the order. Delay at any stage will lead to failures in all other stages. If such delays occur regularly, this will require the creation of buffer stocks to protect against uncertainty.

The direction of further research may be to predict the parameters of the logistics chains of the organization. 


\section{REFERENCES:}

1. Hrabovskyi Y., Yevsyeyev O. (2018). Development of methodological principles of support-preservation engineering work Technological audit and production reserves. № 2/2. P. 43-49.

2. Hu C., Yang Z, Mingjing G. AHP and CA Based Evaluation of Website Information Service Quality: An Empirical Study on High-Tech Industry Information Center Web Portals//Journal Service Science \& Management. 2009. № 3. P. 168-180. DOI: https://doi.org/10.4236/jssm.2009.23020

3. Summary of the Methodology for assesing the Dynamics and Impacts of Electronic Commerce (2004). OECD WPIE Ad Hoc Technucal Expert Group. P. 12.

4. Naumenko M., Hrabovskyi Y. (2018) Elaboration of methodology for designing a publishing and printing web portal. Eastern-European Journal of Enterprise Technologies. № 2/2 (92). Pp. 14-22. DOI: 10.15587/1729-4061.2018.126305

5. Hrabovskyi Y., Brynza N., Vilkhivska O. (2020). Development of information visualization methods for use in multimedia applications. EUREKA: Physics and Engineering. № 1. pp. 3-17.

6. Naumenko M. O. (2018). Vdoskonalennya upravlinnya yakistyu produkciyi vysokotexnologichnyx pidpryyemstv. [Improvement of product quality management of high-tech enterprises. Bulletin of the Economics of Transport and Industry. No. 62, pp. 335-342.

7. Hrabovskyi Y., Fedorchenko V. (2019). Development of the optimization model of the interface of multimedia edition. EUREKA: Physics and Engineering, № 3, pp. 3-12. DOI: 10.21303/2461-4262.2019.00902

8. Pushkar O., Hrabovskyi Y. (2019) Methodology for developing an intelligent user interface for educational publications in the e-learning system. Development Management, № 17(3), pp. 23-34. DOI: 10.21511/dm.17(3).2019.03

\section{БІБЛІОГРАФІЧНИЙ СПИСОК:}

1. Hrabovskyi Y., Yevsyeyev O. Development of methodological principles of support-preservation engineering work. Технолоічний аудит і резерви виробництва. 2018. № 2/2. C. 43-49.

2. Hu C., Yang Z, Mingjing G. AHP and CA Based Evaluation of Website Information Service Quality: An Empirical Study on High-Tech Industry Information Center Web Portals. Journal Service Science \& Management. 2009. № 3. P. 168-180 DOI: https://doi.org/10.4236/jssm.2009.23020

3. Summary of the Methodology for assesing the Dynamics and Impacts of Electronic Commerce. OECD WPIE Ad Hoc Technucal Expert Group. 2004. P. 12.

4. Naumenko M., Hrabovskyi Y., Elaboration of methodology for designing a publishing and printing web portal. Eastern-European Journal of Enterprise Technologies. 2018. № 2/2 (92), pp. 14-22. DOI: 10.15587/1729-4061.2018.126305

5. Hrabovskyi Y., Brynza N., Vilkhivska O. Development of information visualization methods for use in multimedia applications. EUREKA: Physics and Engineering. 2020. № 1. Pp. 3-17.

6. Науменко М.О. Вдосконалення управління якістю продукції високотехнологічних підприємств. Вісник економіки транспорту і промисловості. 2018. № 62. С. 335-342.

7. Hrabovskyi Y., Fedorchenko V., Development of the optimization model of the interface of multimedia edition. EUREKA: Physics and Engineering. 2019. № 3. Pp. 3-12. DOI: 10.21303/2461-4262.2019.00902

8. Pushkar O., Hrabovskyi Y. Methodology for developing an intelligent user interface for educational publications in the e-learning system. Development Management. 2019. № 17-3. P. 23-34. DOI:10.21511/dm.17(3).2019.03 